\title{
整形外科領域の腫瘍性疾患と免疫学的アプローチ
}

\author{
熊本大学医学部整形外科 \\ 本 村 喜代二・北 川 敏 夫
}

\section{Correlations between $T$ cell subpopulation and patients with osteogenic or soft-tissue tumors}

by

\section{K. Motomura and T. Kitagawa}

Department of Orthpedic Surgery, Facu ty of Medicine, Kumamoto University, Kumamoto (Director: Toshio Kitagawa) mors.

Recently, Immuno-therapy plays an important part of therapy for malignant tu-

This time we examined T-cell subpopulation of tumor bearing patients.

Healthy men and benign tumor patients have similar range distribution as controls.

Malignant tumor-patients have lower range than the former.

Especially, a case of Osteosarcoma, 15 years old-girl, showed good correlation between her clinical stage and $\mathrm{T}$-cell subpopulation

The value of preamputation is $45 \%$, and post-amputation $38 \%$, and 2 months after amputation inproved up to $55 \%$.

But appearing metastasis to the lung, it showed decreasing to $28 \%$.

Considering of this case, $T$-cell subpopulation reflected her clinical stage and the activity of host-immunity.

本年 4 月より当科における腫瘍性疾患患者に対して その免疫パラメータとして PHA による Blast formation および Rosette formation による T-cell subpopulation を実施し，T-cell subpopulation に 関して一連の傾向が得られたので報告する.

\section{方法}

原法については Brain'2), Waltrault27)，橘23)24)， 矢田 ${ }^{31)}$ ，らの詳しい文献があるのでこてでは簡単に記 す. リンパ球分離に関しては $3 \%$ ラチン法"6), ナ イロンカラム法5), デキストラン法 ${ }^{12)}$, 重力沈降法7) 等があるが，われわれは $9 \%$ ィコールと $33.9 \%$ ード剂 24: 10 に混合したもの (Lymphoprep)を使 用した. ヘパリン加注射器にて $3 \mathrm{ml}$ の末梢血を採血 し, Lymphoprep に重層後，直ちに $2000 \mathrm{rpm} 10$ 分間 遠沈する. 分離されたリンパ球は Hank's balanced salt solution (H.B.S.S.) で 3 回洗い, 最終 的には同液で $10^{6} / \mathrm{ml}$ に調整する. 乙の時 Gimsa 染
色にてリンパ球の含有率を求めるが通常は $90 \%$ 以上 である. 一方羊赤血球 (S-R B C) あ H.B.S.S. で 3 回洗い, Fetal Calf Serum にて $10^{8} / \mathrm{ml}$ に調整し, 双方の $0.5 \mathrm{ml}$ づつを混合し 1 時間室温に放置後, 24 時間 $4^{\circ} \mathrm{C}$ で反応させ判定する. 判定は $\mathrm{Brain}^{2)}$ らの 基準に従い 5 コ以上 S-R B C を付着せるすのを陽性 とした.

全行程とも無菌操作でなければならない.

$$
\text { 結果 }
$$

コントロールとして健康成人 15 名を選び計測した (表 2). 計測は 2 週間おきに 3 回行いその平均値を求 めた. 20 代における平均值間の平均値 $\mathrm{M}+\mathrm{S}$.D は $61.81 \pm 4.35 \%$ で, 60 代のそれは $56.26 \pm 3.84 \%$ と, 加令に伴う低下が認められる事は諸家の報告9) と一致 する. 一方表 2 の良性腫瘍疾患群の平均值の M+S.D は $61.63 \pm 4.89 \%$ ， 健康人のそれとほぼ差は認め られない，悪性腫瘍群（表 3 ）では，個々の分布は 
表 1 健康成人15名の $\mathrm{T}$ cell population と年 令の変化 (\%) 2 週間隔で計測

(小数点以下四捨五入)

\begin{tabular}{|c|c|c|c|c|c|c|}
\hline & 年. & 性 & 1 回目 & 2 回目 & 3 回目 & 平均 \\
\hline 1 & 22 & 3 & 64 & 68 & 67 & 66.3 \\
\hline 2 & 23 & 오 & 59 & 57 & 61 & 59.0 \\
\hline 3 & 22 & 우 & 70 & 64 & 64 & 66 \\
\hline 4 & 24 & 우 & 59 & 64 & 62 & 61.7 \\
\hline 5 & 23 & 우 & 53 & 56 & 58 & 55.7 \\
\hline 6 & 27 & $\hat{o}$ & 62 & 68 & 64 & 64.7 \\
\hline 7 & 26 & ิิ & 69 & 69 & 65 & 67.7 \\
\hline 8 & 26 & ิิ & 61 & 63 & 58 & 60.7 \\
\hline 9 & 24 & 오 & 58 & 52 & 56 & 55.3 \\
\hline 10 & 27 & 우 & 64 & 59 & 60 & 61 \\
\hline 11 & 66 & $\hat{o}$ & 65 & 60 & 62 & 62.3 \\
\hline 12 & 68 & $\hat{0}$ & 58 & 53 & 56 & 55.7 \\
\hline 13 & 58 & 우 & 56 & 60 & 56 & 57.3 \\
\hline 14 & 71 & 우 & 55 & 52 & 52 & 53 \\
\hline 15 & 60 & 우 & 53 & 55 & 51 & 53 \\
\hline
\end{tabular}

表 2 当科入院良性腫瘍の $\mathrm{T}$ cell population

(\%)

\begin{tabular}{|c|c|c|c|c|}
\hline 断 & $\begin{array}{c}1 \text { 回 } \\
\text { 目 }\end{array}$ & $\begin{array}{c}2 \text { 回 } \\
\text { 目 }\end{array}$ & $\begin{array}{c}3 \text { 回 } \\
\text { 目 }\end{array}$ & 平 \\
\hline $\begin{array}{l}1 \text { Bone cyst } \\
2 \text { Bone cyst } \\
3 \text { Fibrous dysplasia } \\
4 \text { Bone cyst } \\
5 \text { Eibrous dysplasia } \\
6 \text { Ossifying fibroma(?) } \\
7 \text { Chordoma } \\
8 \text { Benign chondroblastoma } \\
9 \text { Giant cell tumor } \\
10 \text { Fibrous dysplasia } \\
11 \text { Bone cyst }\end{array}$ & $\begin{array}{l}64 \\
53 \\
59 \\
66 \\
71 \\
58 \\
56 \\
62 \\
66 \\
64 \\
65\end{array}$ & $\begin{array}{l}62 \\
52 \\
60 \\
69 \\
74 \\
64 \\
56 \\
64 \\
60 \\
59 \\
60\end{array}$ & $\begin{array}{l}64 \\
58 \\
58 \\
69 \\
68 \\
60 \\
54 \\
60 \\
59 \\
57 \\
63\end{array}$ & $\begin{array}{l}63 . \\
54 . \\
59 \\
68 \\
71 \\
60 . \\
55 . \\
62 \\
61 . \\
60 \\
62 .\end{array}$ \\
\hline
\end{tabular}

$37.7 \%$ から $57.3 \%$ 分布が大きいがその M+S.D は

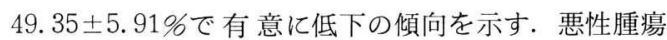
の個々の症例に関しては, 判断する前に, 悪性度の

Grade, c inical stage, 治療の内容, 即ち手術や放 射線療法の有無やその時期, 使用制癌剂や免疫強化剂 の有無等を総合的にふまえて解釈しなければならな い，そうする事でその時点のパラメーターが回復期に あるのか悪化期にあるのかを判断し，それをあとに治 療方針の検討をたてる事に真の意義があるのであり単 に数的解釈にとよ゙まるむのではない（表 4 は以上をま とめたものである).

この例として表 3 case 5 の Osteosarcoma の一 例を検討してみたい.

患者は 15 才で昭和 53 年 2 月初旬に左膝部痛を主 訴として某医を受診, Biopsy およびレ線（図2） により Osteosarcoma と診断され，3 月 22 日当科
表 3 悪性腫瘍疾患の $\mathrm{T}$ cell population (\%)

\begin{tabular}{|l|c|c|c|l|}
\hline & $\begin{array}{c}1 \text { 回 } \\
\text { 目 }\end{array}$ & $\begin{array}{c}\text { 回 } \\
\text { 目 }\end{array}$ & 回 & 平均 \\
\hline 1 Reticulum Cell Sarcoma & 41 & 43 & 51 & 45 \\
2 Lipomyxo-Sarcoma & 39 & 38 & 36 & 37.7 \\
3 Rhabdo myo-Sarcoma & 54 & 58 & 60 & 57.3 \\
4 Parosteal Chondrosarcoma & 53 & 56 & 49 & 52.7 \\
5 Osteosarcoma (死亡) & 45 & 38 & 60 & 47.7 \\
6 Osteosarcoma (外来) & 60 & 58 & 54 & 51.3 \\
7 Multiple Myeloma & 52 & 48 & $\times$ & 50 \\
8 Multiple Myeloma & 58 & 56 & $\times$ & 57 \\
9 Multiple Myeloma & 49 & 46 & $\times$ & 47.5 \\
10 Multiple Myeloma & 52 & 46 & $\times$ & 49 \\
11 Metastasis from Hepatoma & 55 & $\times$ & $\times$ & 55 \\
12 Metastasis from Hepatoma & 38 & 46 & $\times$ & 42 \\
\hline
\end{tabular}

表 4 整形外科腫湯性疾患の $\mathrm{T}$ cell population

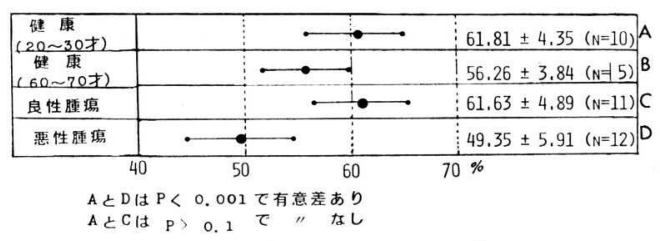

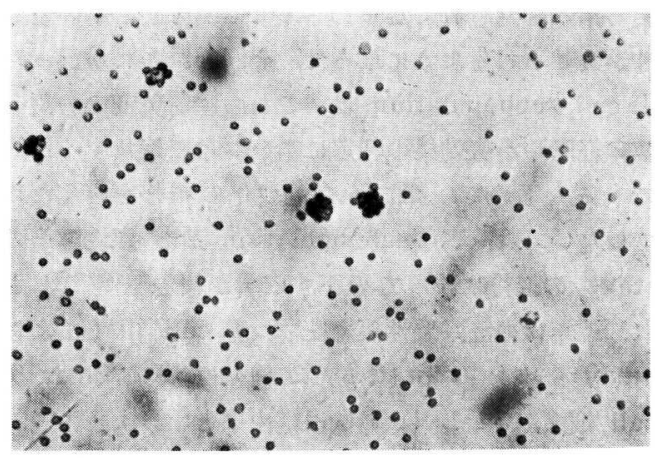

図 1 Rosette formation $(10 \times 20)$

に入院した. 3 月 29 日に左大腿切断術を受け，その 後は装具等による歩行訓練, 登校訓練の後 6 月 7 日退 院した. 外来治療を 続けるも肺転移症状出現のため (図 3)，7月 12 日再入院し 8 月 6 日に死亡した. こ の間の白血球数, リンパ球数, T-cell subpopu ation と治療経過をまとめたのが図 4 であるが，白血 球数は切断前後に著しい变動を示しているにも拘ら ずリンパ球数は常に $1300 / \mathrm{mm}^{3}$ 位を維持しており, T-cell subpopulation 屯術後 3 週間位加ら上昇し, 退院前には $60 \%$ 位にまで回復している. 即ち切断に よる原発巣除去とクレスチンの投与は患者の免疫能の 
改善に有効に作用した事をうかがわせる. しかし肺 転移出現後は，T-cell subpopulation は低下の一途 で，死亡直前には $28 \%$ にまで低下している．乙の間 に投与されたピシバニールや S.S.M はもはや患者の 免度能の改善に有効に作用しえなかった事をうかがわ せる. てのように患者の clinical stage と免疫パラ メーターが常に一致するわけではないが，より多くの パラメーターを採用する事によってより正確で鋭敏な 免度動態を把握する事ができるものと考える.

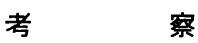

悪性腫瘍の治療法としては外科的手術，制癌剂投与 等の化学療法, および放射線療法が主体を占め, 免疫 療法は未だ一歩譲るとてろである。しかし生体が本来 有している抗腫瘍能力を十分に発揮させうる方法があ れば，前者 3 つの治療法による効果をかなり高める事 ができる事は実験的にも多くの報告15)16117) をみる. てれら腫瘍免疫の主体をなすのがリンパ球，正確には Killer cell や Helper cell, Amplifer cell 等の Thymus derived lymphocytes (T-cell) ${ }^{39923)} \tau$ ある事が確認されてから T-cell の臨床的応用の重要 性が論ぜられるようになった．今回われわれが行った T-cell subpopulation は，乙れら腫瘍免疫の一角を 臨床経過や治療効果の判定に結びつけて追及する目的 で行ったもので， 単なる数的変化の 推移をみるため ではない. T-cell subpopulation が, 悪性腫瘍の stage の進行に伴って 低下する事が報告22)2622728) さ れ，近年は血液系悪性疾患を $\mathrm{T}, \mathrm{B}$ cell 由来により 分類する事も可能になった. 例えば A.L.L. は T cell 畑来, C L L は B cell 由来というように 22 . てのような免度学的事実からわれわれは $\mathrm{T}$ cell の変 動が最も宿主の免度能を反映するパラメーターの $1 つ$ である事 ${ }^{26)}$ から Rosette formation による T-cell subpopulation の変動を追及した. 末梢血におけ る T-cell subpopulation の\%は, 文献上, 矢田 ${ }^{30}$ (1970), Waltraut ${ }^{27)}$ (1971) らが 20〜40\%, Stjernsward $^{21)}(1972)$ が $60 \%$, 小谷 ${ }^{10)}(1972)$, Jondal ${ }^{8}$ （1972）らが50 80\%，矢田 ${ }^{322}$ (1974）が 60\% と近年 は $60 \%$ 付近に落ち着いておりてれは文献等の普及で 方法・使用製品が規格化されたためと考えられ，われ われの実験であだいたい $60 \%$ 前後になった．現 在使 用されている制癌剂のほとんどが宿主の免度能まで抑 制する事はよく知られているが，少くともこれらを使

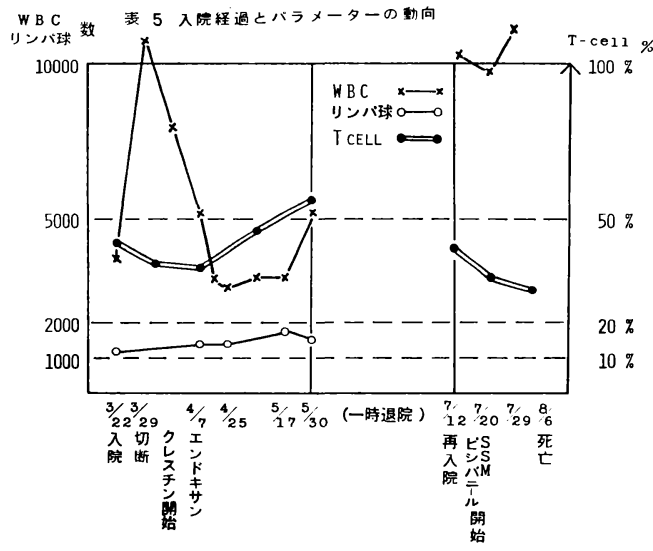

表 5 入院経過とパラメーターの動向

う以上は，その抗腫瘍効果之同時に，免疫能の改善に あ目を向けなければならない事は明らかである，今 回, 使用されているクレスチンむ，最近開発された免

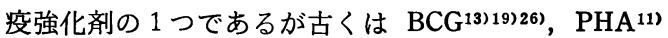
1220125) あ免疫能の活性化に有効である事が知られて おり，てれらが delayed hypersensitivity に関係 する事加皮内反応に応用して, 細胞性免疫能を見る 方法もある．骨肉腫に対しては感受性が低いという事 で一時行われなかった放射線療法も近年の線種の改善 や短期大量照射および開創照射等により再び行われつ つあるが，乙の放射線療法が宿主の免疫能を抑制する 事はよく知られており，やはりてれらによる治療の際 には何らかのパラメーターで宿主の免度能を把握しな ければならない。

Rosette formation による T-cell subpopulation とは別に, P.H.A. が T cell のみを blast 化 させる事(1112)20125) から，乙れを利用してリンパ球の blast 化率を求める方法があるが，われわれあ本法に よる追及を試みたが，諸家が指摘する通り blast 化 したリンパ球同志の凝集，変性が強く，正確な％之 して捕捉できないので，現在はリンパ球の培養液に 3H-Thymidine ${ }^{114) 18229)}$ を加えてその取り込み量 (C.P.M.) 加ら blast 化する能力活性を求める方法に よって症例を検討中であるので次回詳しく報告する予 定である

以上腫瘍免度に占める $\mathrm{T}$ cell の重要性にかんが み，今回われわれは主として T-cell subpopulation について検討を加えたが，今後更に制癌剂各種の免疫 能に及ぼす影響や，免疫強化剂の有用性を種々のパラ 
メーターにより追及し, より正確な臨床応用に役立て る予定である.

結語

1. 健康成人 15 名, 良性腫瘍 11 名, 悪性腫瘍 12 名 について T-cell subpopulation を実施した.

2. 悪性腫瘍群では有意に T-cell subpopulation の低下が認められた.

3.データの判断は年令, 使用薬剂, 併用療法の有 無, clinical stage, 悪性度の grade, 年令等を考慮 したうえで判断しなければならない。

4. 現行の制癌剂は宿主免疫能の抑制があるので可 能な限りその抑制を軽减するために，免疫療法等で宿 主の免度能を強化し，それを客観的に見るために $\mathrm{T}$ cell subpopulation 等のパラメーターの導入が有 効である.

\section{参考文 献}

1) Bender, M. A.: Exp. Cell. Res, 27:221229, 1962.

2) Brain, P. : Clin. exp. Immunol, 6:681688, 1970.

3) Cooms, R. R. A.: Int. Arch. Allergy, 39: 658-663, 1970.

4) Coulson, A. S.: Lancet, Feb 29: 468-469, 1964.

5）橋本信也：移植， $4: 61-66,1964$.

6）橋本信也：移植，5:127-130, 1970.

7) James, L. T.: Blood, 7: 890-896, 1952.

8) Jondal, M.: J. Exp. Med, 136: 207-215, 1972.
9) 岸本 進: 15: 769-773, 1978

10）小谷正彦：熊本医学界雑誌，46：459-466, 1972.

11) Kurt, H.: Lancet, Aug. 10: 305-306, 1963.

12) Ling, N. R. : Lancet, Feb 15: 363-365, 1964.

13) Marshall, W. H. : Lancet, Apr. 6: 773$774,1963$.

14) McDonald, C.: J. Cell. Biol. 29: 209-220, 1966.

15）三井清文: GANN. 62:13-20, 1971.

16）三井清文：臨床免疫，6：985-995, 1974.

17）三井清文: 癌の臨休, 21:783-788, 1975.

18）森陽一：日本血液学会，6：51-61，1972。

19) Pearmain, G. : Lancet, March 23: 637638, 1963.

20) Stevan, D. D. : J. Immunol, 103: 11851195, 1969.

21) Stjernsward, J. : Lancet, June 24: 13521356, 1972.

22）橘 武彦：医学のあゆみ, 88:61-65, 1974.

23）橘 武彦：臨床免疫, 9: 118-127, 1977.

24) 橘 武彦: Medical Technology 5: 787-791, 1977.

25) Tanaka, Y.: Blood, 22: 614-629, 1963.

26）富山次郎：医学のあゆみ, 106：417-422, 1978.

27) Waltraut H. L. : Nature, 230 : 531-533, 1971.

28) Willson, J D.: Lancet, Oct. 9: 788-791, 1971.

29）山井重房：日産婦会誌，26：483-489, 1974.

30) 矢田純一：小児科䪾療，34:315-324，1971.

31) 矢田純一：アレルギー, 23: 692-695, 1974.

32）矢田純一：医学のあゆみ，88：61-65, 1974. 